\title{
DA CONSTITUIÇÃO DE 1934 AO GOLPE DO ESTADO NOVO: AUTORITARISMO E DISPUTAS POLÍTICAS EM TEMPOS DE DEMOCRACIA LIBERAL-BURGUESA
}

\author{
DE LA CONSTITUCIÓN DE 1934 AL GOLPE DEL ESTADO NUEVO: \\ AUTORITARISMO Y DISPUTAS POLÍTICAS EN TIEMPOS DE \\ DEMOCRACIA LIBERAL-BURGUESA
}

FROM THE 1934 CONSTITUTION TO THE NEW STATE COUP: AUTHORITARIANISM AND POLITICAL DISPUTES IN TIMES OF LIBERAL-BOURGEOIS DEMOCRACY

DOI: $10.22481 /$ rbba.v10i01.8761

\begin{abstract}
Carlos Nássaro Araújo da Paixão Instituto Federal Baiano - Campus Serrinha, Bahia, Brasil ID Lattes: http://lattes.cnpq.br/8488928828139958 ORCID: http://orcid.org/0000-0002-5427-4248 Endereço eletrônico: carlos.hyst@gmail.com
\end{abstract}

\section{RESUMO}

Este artigo objetiva analisar a escalada autoritária compreendida entre os anos de 1934 e 1937 e o processo de afastamento político entre Juracy Magalhães, governador da Bahia, e o presidente Getúlio Vargas, que culminou com o golpe do Estado Novo, em 10 de novembro de 1937. Nesse período, foi promulgada a Lei de Segurança Nacional, um dispositivo autoritário em um contexto de formal funcionamento das instituições liberais-burguesas. Após os acontecimentos de novembro de 1935, os decretos de Estado de Guerra e Estado de Sítio, na prática, suspenderam o funcionamento da Constituição de 1934. Por outro lado, havia a movimentação para as eleições que deveriam ocorrer em 1938. Como desdobramento desses fatos, Vargas atuou na perseguição aos seus adversários e antigos aliados. Nessa linha de ação ele estabeleceu intervenção velada na Bahia, em São Paulo e em 


\section{DA CONSTITUIÇÃO DE 1934 AO GOLPE DO ESTADO NOVO: AUTORITARISMO E DISPUTAS POLÍTICAS EM TEMPOS DE DEMOCRACIA LIBERAL-BURGUESA}

Pernambuco, a partir da nomeação de executores do estado de guerra, em 29 de abril de 1937. Juracy Magalhães passou a ser investigado e intimidado pelo Coronel Antônio Fernandes Dantas, o executor do Estado de Guerra na Bahia.

Palavras-Chave: Autoritarismo; Golpe de Estado; Juracy Magalhães; Eleições.

\section{RESUMEN}

Este artículo tiene como objetivo analizar la escalada autoritaria entre los años 1934 y 1937 y el proceso de separación política entre Juracy Magalhães, gobernador de Bahía, y el presidente Getúlio Vargas, que culminó con el golpe del Estado Novo, el 10 de noviembre de 1937 durante este En ese período, se promulgó la Ley de Seguridad Nacional, un dispositivo autoritario en el contexto del funcionamiento formal de las instituciones liberalburguesas. Luego de los hechos de noviembre de 1935, los decretos de Estado de Guerra y Estado de Sitio, en la práctica, suspendieron la vigencia de la Constitución de 1934. Por otro lado, hubo un movimiento hacia las elecciones que se suponía que tendrían lugar en 1938. Como A raíz de estos hechos, Vargas actuó en la persecución de sus opositores y ex aliados. En esta línea de acción, estableció una intervención velada en Bahía, São Paulo y Pernambuco, luego del nombramiento de los ejecutores del estado de guerra, el 29 de abril de 1937. Juracy Magalhães comenzó a ser investigado e intimidado por el coronel Antônio Fernandes Dantas, el ejecutor del Estado de Guerra en Bahía.

Palabras-clave: Autoritarismo; Golpe de Estado; Juracy Magalhães; Elecciones.

\footnotetext{
ABSTRACT

This article aims to analyze the authoritarian escalation between the years 1934 and 1937 and the process of political separation between Juracy Magalhães, governor of Bahia, and President Getúlio Vargas, which culminated with the coup of the Estado Novo, on November 10, 1937. During this period, the National Security Law was enacted, an authoritarian device in the context of the formal functioning of liberal-bourgeois institutions. After the events of November 1935, the State of War and State of Siege decrees, in practice, suspended the operation of the 


\section{DA CONSTITUIÇÃO DE 1934 AO GOLPE DO ESTADO NOVO: AUTORITARISMO E DISPUTAS POLÍTICAS EM TEMPOS DE DEMOCRACIA LIBERAL-BURGUESA}

1934 Constitution. On the other hand, there was a movement towards the elections that were supposed to take place in 1938. As a result of these facts, Vargas acted in pursuit of his opponents and former allies. In this line of action, he established a veiled intervention in Bahia, São Paulo and Pernambuco, after the appointment of executors of the state of war, on April 29, 1937. Juracy Magalhães started to be investigated and intimidated by Colonel Antônio Fernandes Dantas, the executor of the State of War in Bahia.

Keywords: Authoritarianism; Coup d'etat; Juracy Magalhães; Elections.

\section{DA PROMULGAÇÃO DA CONSTITUIÇÃO DE 1934 À APROVAÇÃO DA "LEI MONSTRO"}

Antes mesmo da promulgação da Carta Constitucional, em julho de 1934, Getúlio Vargas apresentava sinais de que não estava satisfeito com o resultado do texto que estava em construção pelos deputados constituintes. No dia 03 de março de 1934, o ainda chefe do Governo Provisório, recebeu três dos vinte e seis membros designados para a Comissão responsável pela redação preliminar do projeto da Constituição: Raul Fernandes, Levi Carneiro e Carlos Maximiliano, além do líder da maioria, deputado baiano e correligionário de Juracy Magalhães, Medeiros Neto. Ao ler o projeto, as impressões de Vargas sobre o documento, registradas em seu diário, não foram das mais lisonjeiras: "Achei-o um tanto inclinado ao parlamentarismo, reduzindo muito o poder do executivo e, principalmente, complicando a máquina burocrática, de modo a dificultar a administração” (VARGAS, 1995, p.273).

No dia em que a nova Constituição entrou em vigor, 16 de julho de 1934, novamente, Vargas demonstrou descontentamento e desaprovação com relação ao que ele considerava um entrave demasiado ao exercício do poder executivo. Diga-se, do exercício do seu poder: "Afinal, chegou esse dia. Entre festas e demonstrações de regozijo, foi promulgada a nova Constituição. Parece-me que ela será mais um entrave do que uma fórmula de ação" (VARGAS, 1995, p.307). Ainda de acordo com o julgamento de Vargas, registrado em um discurso não proferido, de caráter crítico à nova Constituição: "Quem examinar atentamente a matéria da nova Constituição verificará, desde logo, que ela fragmenta e dilui a autoridade, instaura a 


\section{DA CONSTITUIÇÃO DE 1934 AO GOLPE DO ESTADO NOVO: AUTORITARISMO E DISPUTAS POLÍTICAS EM TEMPOS DE DEMOCRACIA LIBERAL-BURGUESA}

indisciplina e confunde a cada passo as atribuições dos poderes da República", vaticinando: "Creio que serei o primeiro revisionista da Constituição." ii

$\mathrm{Na}$ verdade, a desconfiança de Vargas com a capacidade da ordem liberal em resolver os desafios apresentados pela crise econômica, e a consequente depressão do início da década de 1930, já ficou patente na ocasião da instalação da Assembleia Nacional Constituinte, em 15 de novembro de 1933. Destacou, desse modo, a conjuntura de crise econômica internacional que desorganizou os sistemas econômicos e sociais, levando governos a adotarem medidas excepcionais para a resolução dos problemas que surgiram:

O momento em que vamos reformar o arcabouço institucional da Nação é de perspectivas inquietantes e excepcionais, diante das perturbações políticas e econômicas que o singularizam. Abalados na sua autoridade, os governos procuram reagir, adaptando-se às contingências sociais. Aponta-se como fator precípuo da perturbação alarmante o desequilíbrio econômico mundial [...] (VARGAS, 1938, p30).

Aproveitou, então, a oportunidade para defender um Estado mais forte, com maior poder de intervenção, com a capacidade de ser um mecanismo organizador e disciplinador da sociedade. Além disso, rechaçou a ideia de um modelo de organização estatal que fosse copiado de realidades estranhas à brasileira.

O Estado, qualquer que seja o seu conceito segundo as teorias, nada mais é, na realidade, do que o coordenador e disciplinador dos interesses coletivos, ou a sociedade organizada como poder, para dirigir e assegurar o seu progresso. Toda estrutura constitucional implica, por isso, na estrutura das funções do Estado. Ao empreender tão transcendente tarefa, devemos estar atentos às nossas realidades políticas e econômicas e sobrepor os ensinamentos das nossas experiências à sedução das ideias em voga entre outros povos, expressão, quase sempre, de fenômenos sociais especialíssimos, que se modificam de país para país, em intensidade e efeitos (VARGAS, 1938, p. 30$31)$.

De acordo com Lira Neto (2013), não foi apenas Vargas que demonstrou descontentamento com o retorno da ordem democrática. $\mathrm{O}$ alto escalão do setor militar também não ficou satisfeito com o que se considerava um caráter excessivamente liberal e limitador do poder executivo, por parte da fórmula desenvolvida no texto constitucional. Aquilo que era elemento basilar do ordenamento democrático parlamentar, qual seja, o livre debate de ideias, muitas vezes exaltado, era visto por muitos generais como um caráter inequívoco e inadmissível 


\section{DA CONSTITUIÇÃO DE 1934 AO GOLPE DO ESTADO NOVO: AUTORITARISMO E DISPUTAS POLÍTICAS EM TEMPOS DE DEMOCRACIA LIBERAL-BURGUESA}

de anarquia e sugeriram um alto golpe, com a manutenção de Vargas no exercício de um poder autocrático.

O general Manuel Rabelo, que desde março de 1933 estava no comando da $7^{\mathrm{a}}$ Região Militar, no Recife, enviou a Góes Monteiro uma carta na qual sugeria a dissolução da Assembleia, a manutenção de Getúlio como chefe do governo e a aplicação extensiva da Constituição autocrática gaúcha, escrita por Júlio de Castilhos (LIRA NETO, 2013, p. 179).

No período compreendido entre 1934 e 1937 consolidou-se a hegemonia dos grupos regionais. Foi posta em prática a execução de uma política conservadora, propiciada pela acomodação das disputas anteriores e o retorno dos exilados em 1930 e 1932. O Congresso, após as eleições de 1934, apresentou feições oligárquicas ainda mais claras devido à vitória dos partidos e candidatos das interventorias (DULCI, 1986, p. 61). Além disso, as eleições majoritárias para presidente, governadores e prefeitos foram decididas de maneira indireta nas casas legislativas. Conforme observou Otávio Soares Dulci, “a pacificação entre as oligarquias e os militares fez com que prosperassem tendências autoritárias, visando restringir o âmbito das liberdades públicas” (DULCI, 1986, p. 61). De acordo com Paulo Brandi (2010):

\footnotetext{
Apesar de todas as inovações introduzidas, a Constituição de 1934 propunha um modelo político liberal e ainda nitidamente federalista, portanto muito mais identificado com as oligarquias regionais do que com o projeto centralizador dos "tenentes". Conservando vários aspectos da Constituição de 1891, a nova Carta preservava o regime federativo e assegurava eleições por sufrágio universal e direto para todos os cargos executivos, de presidente da República a governadores e prefeitos. Mantinha, porém, o sistema de representação classista. No capítulo dos direitos e garantias individuais, assegurava total liberdade de crença, reunião, associação política e imprensa ${ }^{\text {iii }}$.
}

Devido à aprovação deste capítulo, referente aos direitos e garantias individuais, houve uma espécie de descompressão política. Esse fato estimulou mobilização social mais intensa, em "um franco processo de radicalização"iv com a formação de agremiações partidárias e não partidárias das mais diversas matizes ideológicas, incluindo os partidos que se formaram para os pleitos eleitorais que se iniciaram em 1933 com a composição da Assembleia Nacional Constituinte, a Ação Integralista Brasileira (criada em 1932) e a Aliança Nacional Libertadora; debates e críticas da imprensa oposicionista ao governo, resultado do fim da censura; além de greves deflagradas pelos trabalhadores dos diversos setores como os funcionários dos Correios 


\section{DA CONSTITUIÇÃO DE 1934 AO GOLPE DO ESTADO NOVO: AUTORITARISMO E DISPUTAS POLÍTICAS EM TEMPOS DE DEMOCRACIA LIBERAL-BURGUESA}

e Telégrafos (VARGAS, 1995, p. 347), ferroviários (arquivo nacional), Trabalhadores do fumo, entre outros (Diário de Notícias, 5/4/35; PANDOLFI, 2007, p. 31).

Vargas já havia dado mostras de que não estava satisfeito com a Constituição. Além de todas as reservas que demonstrou com relação à Carta Magna, ele lamentava, no seu entendimento, a perda da capacidade de ação do presidente da República, principalmente pelo fato de ter sido cerceado dos meios necessários e indispensáveis à manutenção da ordem (PANDOLFI, 2007, p. 29). O presidente, eleito de maneira indireta, não via com bons olhos a participação política de setores mais ampliados da sociedade e, muito menos, a ação autônoma de trabalhadores que buscavam os seus direitos a partir da greve, paralisando os setores mais diversos e considerados essenciais, desobedecendo aos ditames do Ministério do Trabalho que os queria subordinados à sua estrutura, de caráter corporativista. Uma amostra da truculência e da forma intransigente com que o governo Vargas tratava os considerados rebeldes e insubordinados foi a sua atitude para com os grevistas dos Correios e Telégrafos. Todos os líderes do comando de greve foram sumariamente exonerados e o ministro da Viação foi elogiado por ter se mantido "firme e enérgico" (VARGAS, 1995, p. 347).

Desse modo, para reforçar a autoridade nas mãos do poder central, foi editado um Decreto de número 23.873, de 15 de fevereiro de 1934, antes mesmo da promulgação da constituição, a partir do qual foi organizado o Conselho de Defesa Nacional. O órgão tinha por objetivo, em tese, ser o responsável pelas questões referentes à defesa nacional e que havia sido criado ainda em 1927. A própria Constituição, promulgada em 16 de julho de 1934, de caráter liberal, fazia menção a um órgão denominado Conselho Superior de Segurança Nacional, que teria os mesmos objetivos, além da prerrogativa da regulação de concessão de terras, vias de comunicação e o estabelecimento de indústrias no perímetro de cem quilômetros das fronteiras. ${ }^{\vee}$

O Decreto número 7, de 3 de agosto de 1934, alterou o nome do Conselho de Defesa Nacional, para Conselho Superior de Segurança Nacional, definindo que suas funções seriam reguladas por lei e o seu organograma seria o seguinte: a presidência caberia ao presidente da República; os membros seriam os ministros de Estado, o chefe do Estado-Maior do Exército e o chefe do Estado-Maior da Marinha ${ }^{\text {vi }}$.

Getúlio Vargas, em 23 de novembro de 1934, mencionou a necessidade da instalação do referido Conselho, em conversa com o general Pantaleão, então chefe do Gabinete Militar da Presidência da República (VARGAS, 1995, p. 346). O órgão foi finalmente instalado em 27 


\section{DA CONSTITUIÇÃO DE 1934 AO GOLPE DO ESTADO NOVO: AUTORITARISMO E DISPUTAS POLÍTICAS EM TEMPOS DE DEMOCRACIA LIBERAL-BURGUESA}

de novembro de 1934, tendo como seu primeiro secretário geral o mesmo general Pantaleão (VARGAS, 1995, p. 346).

Entre os dias 22 e 24 de janeiro de 1935, Getúlio Vargas destacou o seguinte fato, em seu diário: "Continuam os preparativos para a Lei de Segurança, cujo projeto está pronto, com a assinatura da maioria dos representantes e um regular preparo da opinião na imprensa" (VARGAS, 1995, p. 355). O projeto de lei foi apresentado na Câmara no dia 25 de janeiro e foi recebida com alguma resistência no parlamento (VARGAS, 1995, p. 355). Nos últimos dias desse mês, voltou a apontar, no mesmo documento, duas preocupações fundamentais que ocuparam a sua atenção, eram elas: "o projeto da Lei de Segurança Nacional e a eleição dos representantes classistas", para tratar dos temas, foram convocados ao Palácio Guanabara Antônio Carlos, presidente da Câmara dos Deputados e Raul Fernandes, líder da maioria no Congresso (VARGAS, 1995, p. 356). Sobre o projeto de lei, Raul Fernandes "ponderou a necessidade de alguns retoques ao projeto, na própria Comissão de Justiça, para diminuir a resistência do Plenário" (VARGAS, 1995, p. 356). O que pode indicar resistência de certos setores da minoria parlamentar.

Vargas estava efetivamente empenhado em fazer aprovar este projeto de lei. Ele cobrou de maneira contundente ao líder da maioria que trabalhasse em favor desse objetivo, criticando o que seriam vacilações e displicências dos parlamentares. Usou como intermediários para tal incumbência, novamente, Antônio Carlos e Vicente Rao, respectivamente presidente da Câmara e ministro da Justiça (VARGAS, 1995, p. 358). Vicente Rao, inclusive, atuou como intermediário entre o presidente e integrantes da bancada paulista que foram ao Palácio Rio Negro, em Petrópolis, discutir o projeto e garantir o apoio paulista à medida, através dos deputados Cardoso de Melo e Morais (VARGAS, 1995, p. 359). O apoio de São Paulo, através do Partido Constitucionalista, do então interventor Armando Sales, se deu a despeito do propalado liberalismo e defendeu, através da Lei de Segurança Nacional, o fortalecimento do poder presidencial, em detrimento do controle previsto no texto constitucional $^{\text {vii }}$.

A iniciativa de enviar um projeto de lei, denominado Lei de Segurança Nacional, através do ministro da Justiça Vicente Rao, que tratasse da definição de crimes contra a ordem política e social, foi uma reação imediata de Vargas contra o processo crescente de mobilização dos diferentes setores das esquerdas e "o surto de greves e movimentos operários"viii. Some-se a esta radicalização do cenário político-social, as conspirações na caserna que quase resultaram em golpe militar, tendo como pretexto a questão em torno do aumento de vencimento dos 


\section{DA CONSTITUIÇÃO DE 1934 AO GOLPE DO ESTADO NOVO: AUTORITARISMO E DISPUTAS POLÍTICAS EM TEMPOS DE DEMOCRACIA LIBERAL-BURGUESA}

oficiais discutido no parlamento ${ }^{\text {ix }}$. Vargas buscara manipular o clima em que o país vivia e se utilizava disso para pressionar a aprovação da lei: “A repressão policial de alguns movimentos extremistas cria motivo psicológico para apressar o andamento da Lei de Segurança" (VARGAS, 1995, p. 364).

A Lei de Segurança Nacional foi finalmente aprovada, em 28 de março de 1935, por ampla maioria, 121 votos a favor, e apenas 23 contrários. Essa lei, na prática, suspendia uma série de direitos que eram garantidos pela Constituição, há pouco promulgada. Efetivamente, era uma invenção jurídica "que garantia o controle e a repressão mais eficaz contra os inimigos do regime" (NETO, 2013, p. 205). Além disso:

Incorriam nos dispositivos da lei todos os que tentassem o recurso da força como meio de acesso ao poder, que estimulassem manifestações de indisciplina nas forças armadas, que atentassem contra pessoas ou bens por motivos ideológicos ou doutrinários e que tentassem executar planos de desorganização ou greves nos serviços públicos. Nesses casos, foram previstas penalidades de um a dez anos de prisão. A lei estabeleceu também sanções para jornais e emissoras de rádio que veiculassem matérias consideradas subversivas, previu a cassação de patentes de oficiais das forças armadas e autorizou o chefe de polícia do Distrito Federal a fechar entidades sindicais suspeitas ${ }^{\mathrm{x}}$.

A Lei de Segurança Nacional era um dispositivo autoritário que, de fato, e de direito, dotava de poderes discricionários o poder executivo federal e todo o aparato de segurança, representado, principalmente, pela Polícia do Distrito Federal, sob o comando de Filinto Müller. Desse modo, os adversários, transformados em subversivos e antipatrióticos, não dispunham mais de quaisquer garantias jurídicas para a sua defesa. A aprovação da lei ocorreu com um significativo número de votos de deputados autodeclarados liberais, estrangulando uma Constituição cujo conteúdo era majoritariamente liberal. Nesse caso, o apelo à ordem e o horror da classe dominante e de setores da classe média quanto às greves e às mobilizações populares falou mais alto do que uma suposta coerência de ideais.

Na imprensa, de oposição liberal ao governo, foram tecidas duras críticas à lei. O jornal Correio da Manhã ao trazer o conteúdo literal do documento fez a seguinte referência: "o monstro que a República Nova vai dar ao país” (CORREIO DA MANHÃ, 27/03/1935). Na edição do dia seguinte, o periódico publicou o resumo do discurso de um deputado da minoria que criticou o artigo referente à cassação dos sindicatos e definiu que a Câmara, ao aprovar o 


\section{DA CONSTITUIÇÃO DE 1934 AO GOLPE DO ESTADO NOVO: AUTORITARISMO E DISPUTAS POLÍTICAS EM TEMPOS DE DEMOCRACIA LIBERAL-BURGUESA}

projeto, estava "apenas tratando de empalhar o cadáver da democracia liberal (CORREIO DA MANHÃ, 28/03/1935).

Na Bahia, o jornal A Tarde, representante da oligarquia-liberal-burguesa, também se manifestou contrário à aprovação da lei, no âmbito da Câmara dos Deputados, denominando-a de Lei-Espantalho. O A Tarde, ao iniciar o artigo crítico, interrogou o porquê da lei, e para que ela foi aprovada. Em seguida, questionou a legitimidade do parlamento que a aprovou, uma vez que, em meados de 1934, a partir de uma manobra do regimento, o mandato dos deputados constituintes foi prorrogado até junho de 1935. O artigo questiona: "Então por que uma Câmara em final de prorrogação de mandato, ao apagar das luzes, sem prestígio público nem seriedade doutrinária, aprova tão extravagante documento?” (A TARDE, 04/04/1935).

No entendimento do autor do artigo, a Lei de Segurança apresentou como erro fundamental o efeito de "intranquilizar e agitar o ambiente em que esta República de maos costumes vae arrastando a sua pobreza e a sua indifferença” (A TARDE, 04/04/1935). Além disso, denunciou a incoerência daqueles que votaram uma lei com características abertamente autoritárias, após terem promulgado uma Constituição de cariz liberal:

Pois a Câmara dos srs. deputados [...]. Sacrificou-se pela inconherencia de que se não redimirá. Foi liberal em 34 e oppressiva em 35. Com a mão direita rubricou a Constituição e com a mão esquerda a Lei de Segurança Nacional. Soffrerá com isso um juízo severo. (A TARDE, 04/04/1935).

Para finalizar, há uma previsão, que não se sustentará, de que ao aprovar uma "lei inoperante e impopular", este documento estaria destinado a "bracejar no vácuo das sancções theoricas" (A TARDE, 04/04/1935). A crítica liberal da Lei se deu a partir do atropelamento dos tramites do regimento e do processo para a aprovação da mesma, bem como dos elementos autoritários e teoricamente antiliberais aprovados, tanto é que foram apontadas as contradições entre a carta magna aprovada em 1934 e a "Lei-Espantalho", ou "Lei Monstro", aprovada em 1935.

O jornal Diário da Bahia, de propriedade do deputado constituinte, depois senador, Pacheco de Oliveira, aliado de primeira hora do interventor, depois governador, Juracy Magalhães, saiu em defesa da "Lei Monstro". O artigo de opinião iniciou com uma declaração de apoio incondicional ao documento: "Tenho deante de mim a Lei de Segurança em sua redacção final e estou plenamente satisfeito com ela. Que o dr. Getúlio Vargas não lhe negue sancção." (DIÁRIO DA BAHIA, 04/04/1935). Em seguida, de maneira desdenhosa, buscou 


\section{DA CONSTITUIÇÃO DE 1934 AO GOLPE DO ESTADO NOVO: AUTORITARISMO E DISPUTAS POLÍTICAS EM TEMPOS DE DEMOCRACIA LIBERAL-BURGUESA}

desqualificar todas as críticas tecidas à lei, apelando para o dever de lealdade para com o regime, justificando, entre outras coisas, que os falsos adeptos devam ser punidos por ela:

Todo elemento falsamente identificado com o regimem em vigor, desde que desvirtuar ou aja por facto no sentido de seu desprestígio também este se, recorreu a acções extremadas, está logicamente incurso em penas sabiamente previstas (DIÁRIO DA BAHIA, 04/04/1935).

Usou desse tom ameaçador para reforçar que, não apenas integralistas e comunistas, expressão dos extremismos políticos daquela conjuntura, estariam sujeitos aos rigores punitivos da lei, mas todos aqueles, incluindo-se os liberais que, porventura, "ultrapassassem os limites" do direito da oposição, cuja ação deveria se manter "dentro do espírito da Constituição" (DIÁRIO DA BAHIA, 04/04/1935).

A defesa foi ainda mais enfática quando qualificou a lei como "um monumento jurídico que nos honra" e que seria uma "affirmativa de estabilidade social, garantia de tranquilidade para o paiz", afirmando que "só temerão os conspiradores e confucionistas" (DIÁRIO DA BAHIA, 04/04/1935). Na prática, o artigo defendeu a ideia de que quem era contrário à lei só poderia estar envolvido em conspirações e subversões, bastava o cidadão se subordinar ao regime que ele não seria enquadrado como uma ameaça à segurança nacional. $\mathrm{O}$ mesmo argumento valia para aqueles que criticavam os elementos de censura à imprensa. Na opinião do jornal, a lei não censurava, apenas impunha as necessidades de agir de acordo com "regimem de responsabilidades", e de "assegurar para o desenvolvimento nacional um arejado ambiente de ordem e segurança” (DIÁRIO DA BAHIA, 04/04/1935).

E, para finalizar, havia uma sintonia com o clima de polarização ideológica e certa histeria conspiracionista, que foi habilmente manipulado por Vargas e os seus aliados mais próximos, quando defendeu que a aprovação da lei foi bem vinda: "Bem compehendo a urgência de se sufocar tendências desagregadoras, com o incentivo de ordem, de paz e de trabalho.” (DIÁRIO DA BAHIA, 04/04/1935). Esse discurso refletia o temor das classes dominantes diante "das reivindicações das classes operárias e médias e de todo movimento ligado à vida política do país" (CARONE, 1974, p. 331). Nesse sentido, foi “contra as justas manifestações de inquietude da época que as novas classes dirigentes se manifestam, tentando impor a Lei de Segurança Nacional" (CARONE, 1974, p. 331).

A aprovação da Lei de Segurança Nacional, e sua sanção por Vargas, em 4 de abril de 1935, portanto, pode ser entendida em um contexto de radicalização das lutas de classe, e de 


\section{DA CONSTITUIÇÃO DE 1934 AO GOLPE DO ESTADO NOVO: AUTORITARISMO E DISPUTAS POLÍTICAS EM TEMPOS DE DEMOCRACIA LIBERAL-BURGUESA}

disputas de projetos de poder, entre trabalhadores urbanos, setores médios, oligarquias e diversas frações da burguesia. A emergência de greves, manifestações por causa dos baixos salários e do aumento do custo de vida, a organização política das classes trabalhadoras, a formação de frente única de caráter popular e antifascista, teve como resposta um dispositivo jurídico que atropelou a Constituição e, na prática, suspendeu as suas garantias de direitos civis e individuais. Em nome da ordem, setores das classes dominantes abriram mão de quaisquer escrúpulos liberais democráticos, criando as bases para uma escalada autoritária do Estado.

\section{O LEVANTE COMUNISTA DE 1935 E O PRETEXTO PARA A ESCALADA AUTORITÁRIA}

Em novembro de 1935, eclodiram revoltas comunistas em quartéis de Natal, Recife e Rio de Janeiro. A insurreição, que tinha como líder Luís Carlos Prestes, buscava constituir um governo nacional de caráter revolucionário, o que poderia ser a ante sala para a instalação de um regime socialista no país. Não se sabe se por precipitação, ou desinformação, o levante foi rapidamente controlado pelas forças legalistas e os seus participantes foram perseguidos, mortos e presos. Além disso, foram vítimas de condições brutais nas cadeias, submetidos às torturas. Toda essa ação repressiva foi comandada por Filinto Muller, chefe de Polícia do Distrito Federal.

Esse fato atingiu diretamente o ambiente familiar e o círculo mais íntimo de amizades de Juracy Magalhães. O seu irmão, Eliézer Magalhães, teria participado das ações conspiratórias e da revolta frustrada e também era integrante da equipe de governo do prefeito do Rio de Janeiro, Pedro Ernesto, implicado, igualmente, como um participante no levante. Em razão disso, ele teve que fugir do Brasil para não ser preso (GUEIROS, 1996, p. 174). O então governador da Bahia ainda lamentou o fato de que a rebelião teria causado o rompimento entre antigos companheiros de 1930, levando a uma situação em que, por exemplo, ele e Agildo Barata, estivessem em campos diferentes, àquela conjuntura “[...]vejam como é contraditório e imprevisível o destino dos homens. Nessa Intentona, os velhos companheiros de 30 se dividiam, lutando em campos opostos." (GUEIROS, 1996, p. 172) (grifo nosso).

Além do constrangimento pessoal, Juracy Magalhães passou a enfrentar a desconfiança daqueles que estavam imbuídos na "caça aos subversivos", acerca da sua suposta participação no movimento. Isso devido à proximidade que ele mantinha com pessoas que suposta, ou 


\section{DA CONSTITUIÇÃO DE 1934 AO GOLPE DO ESTADO NOVO: AUTORITARISMO E DISPUTAS POLÍTICAS EM TEMPOS DE DEMOCRACIA LIBERAL-BURGUESA}

sabidamente, tinham ideias consideradas perigosas, a exemplo do seu irmão e dos seus companheiros de 1930, Pedro Ernesto e Agildo Barata.

A suspeita era tão séria que o seu correligionário e aliado de primeira hora, Clemente Mariani, precisou escrever uma longa carta a Getúlio Vargas para convencer o presidente de que o governador da Bahia era leal ao regime e aos ideais democráticos, contrário às ações extremistas. Além disso, justificou como boatos e denúncias infundadas a participação do Eliezer Magalhães que, a despeito de demonstrar simpatias pelo socialismo, seria incapaz de agir para derrubar o governo constitucional. Atribuiu as suspeitas a ação de adversários políticos que teriam espalhado notícias falsas em jornais sabidamente "seabristas" (CPDOC/FGV, CMa pi. Mariani, C.1935. 11. 27).

O levante de 1935 foi o pretexto perfeito para que Vargas se empenhasse cada vez mais no processo de fechamento do regime, iniciado com a aprovação da LSN. Já no dia 25 de novembro, através do seu ministro da Justiça, fez aprovar no Congresso o decreto do Estado de Sítio, que deveria, imediatamente, vigorar em todo o país por um período de um mês. A aprovação teve, na Câmara, o voto de 172 votos, contra 52. Entre aqueles que foram contrários, o destaque foi para a bancada gaúcha, liderada pelo governador Flores da Cunha, que argumentava ser desnecessária a vigência do Estado de Sítio para áreas do país que não foram atingidas pela rebelião (VARGAS, 1995, p. 445; GUEIROS, 1996, p. 174).

Logo após essa primeira vitória de Vargas, em dezembro de 1935, iniciaram-se as articulações para a emenda à LSN, afim reforçar ainda mais o seu caráter repressivo, além de emenda à Constituição "que permitisse certas medidas enérgicas e prontas, no propósito de intimidar os conspiradores e afastar os rebeldes dos centros de sua atuação" (VARGAS, 1995, p. 445). A reforma da LSN foi sancionada no dia 14 de dezembro de 1935 . Denominada de Lei $\mathrm{n}^{\mathrm{o}}$ 136, de 1935, “tornava mais enérgicas e ágeis as medidas de repressão contra os crimes de subversão à ordem política e social" (VARGAS, 1995, p. 454).

Em 17 de dezembro, Vargas comemorou a aprovação de três emendas à Constituição, que, na prática, suspendia a sua validade: “Em sessão memorável, a Câmara dos Deputados aprovou as três emendas à Constituição. A primeira passou por 210 votos contra 59, e as outras, por uma diferença ainda maior" (VARGAS, 1995, p. 456). Juracy Magalhães recordou esse fato da seguinte maneira: 


\section{DA CONSTITUIÇÃO DE 1934 AO GOLPE DO ESTADO NOVO: AUTORITARISMO E DISPUTAS POLÍTICAS EM TEMPOS DE DEMOCRACIA LIBERAL-BURGUESA}

Uma [emenda] autorizando a declaração do estado de guerra, outra outorgando ao Executivo o direito de cassar patentes de oficiais da ativa, e a terceira autorizando a demissão sumária de qualquer funcionário, ativo ou inativo, envolvido em rebeliões. Era o ovo da serpente, a semente do Estado Novo (GUEIROS, 1996, p. 174) (grifo nosso).

Apenas alguns dias depois, em 21 de dezembro, foi aprovada a autorização, na Câmara dos Deputados e no Senado, para a prorrogação do Estado de Sítio por mais noventa dias e a permissão para que Vargas pudesse equipará-lo ao decreto do Estado de Guerra, através do Decreto Legislativo $\mathrm{N}^{\mathrm{o}}$ 8, de 1935. Utilizando-se dessa prerrogativa, Vargas prorrogou o Estado de Sítio no dia 23 de dezembro (VARGAS, 1995, p. 457-459).

Já em janeiro de 1936, iniciaram-se as tratativas para a criação da Comissão Nacional de Repressão ao Comunismo, para combater todos que, de alguma maneira, participaram da revolta de 1935. De acordo com Juracy Magalhães, a Comissão tornou-se uma espécie de inquisição do regime de Vargas, ela "destinava-se a deter o avanço das ideias contrárias ao sistema. E, com a decretação do estado de guerra, ficavam suspensas todas as garantias constitucionais que interferissem com a segurança nacional.” (GUEIROS, 1996, p. 174). Em carta enviada a Vargas, "o governador da Bahia, [...], manifestou-se contrário à organização desta comissão" (VARGAS, 1995, p. 468).

A oposição de Juracy Magalhães à Comissão tinha um motivo pessoal: a perseguição sofrida pelo seu irmão Eliézer, perpetrada pelo presidente da mesma, Adalberto Correia. Mas, não apenas o governador passou a ser ameaçado:

O jacobino Adalberto Correia queria a cabeça de gene graúda e bem próxima ao governo. Dizia ter recebido informações consistentes que incriminavam Eliézer Magalhães, irmão de Juracy, e Odilon Batista, filho de Pedro Ernesto, não só como simpatizantes da ANL, mas como cúmplices do levante de Novembro" (NETO, 2013, p. 264).

Em março de 1936, Juracy Magalhães enviou uma carta ao presidente, em formato de denúncia, contra as perseguições sofridas pelo seu irmão e pelo prefeito do Rio de Janeiro, Pedro Ernesto. Segue o teor do documento:

Seguramente informado propósitos escandalosos e mesquinhos deputado Adalberto Correia contra Pedro Ernesto e Eliezer fico confiando cegamente alto critério eminente Chefe evitará intervenções indébitas intuitos perseguições consequência interesses advocacia contrariados. Submeter-meei qualquer deliberação oriunda consciência espirito justiça Vossência, mas 


\section{DA CONSTITUIÇÃO DE 1934 AO GOLPE DO ESTADO NOVO: AUTORITARISMO E DISPUTAS POLÍTICAS EM TEMPOS DE DEMOCRACIA LIBERAL-BURGUESA}

não trepidarei lutar contra caricatos Robespierres ousam impor-se pela violência a consideração dos homens públicos do País (sic) (CPDOC/FGV, GV c 1936.03.10/1)

O governador de Pernambuco, Carlos de Lima Cavalcanti, do mesmo modo, passou a sofrer as mesmas acusações. Além disso, "o chefe de polícia do Distrito Federal, Filinto Müller, passou a exercer cerrada vigilância sobre todos os membros do governo, inclusive ministros de Estado e diplomatas de carreira"xi . Nesse caso, Juracy Magalhães apelou para a intervenção de Vargas na questão do envolvimento do seu irmão no movimento de novembro de 1935, mas o presidente já havia montado toda uma rede de espionagem que atingia, inclusive, alguns dos seus aliados mais próximos.

A prisão de luís Carlos Prestes ocorreu nos primeiros dias de março de 1936. Mediante a apreensão dos documentos do líder da ANL, as forças da repressão, representadas por Filinto Muller e Adalberto Correia, respectivamente, chefe de Polícia e presidente da Comissão de Repressão ao Comunismo, defendiam medidas ainda mais "enérgicas" contra o que eles consideravam a ameaça de novas conspirações e articulações contra o regime. O deputado Adalberto Correia defendia, inclusive, a pena de morte por fuzilamento, além da necessidade do estabelecimento de um decreto de Estado de Guerra, mais uma reforma da Constituição, desidratando ainda mais o documento e, pela primeira vez, já se aventava a possibilidade de um golpe de Estado. Na mesma reunião em que essas ideias foram levantadas discutiu-se, novamente, a situação de Pedro Ernesto e Eliezer, sendo considerada a demissão dos respectivos cargos (VARGAS, 1995, p. 488-489).

Em 21 de março de 1936, o Decreto de número 702, instaurou o Estado de Guerra no país, por um período de noventa dias. Na prática, o decreto garantia para o presidente Getúlio Vargas poderes ditatoriais e suspendia todas as garantias individuais estabelecidas na Constituição, além das imunidades dos parlamentares (VARGAS, 1995, p. 489).

O decreto do Estado de Guerra foi anunciado na edição do A Tarde do dia 24 de março de 1936 e a justificativa era que havia indícios de nova investida extremista contra o regime. Após o decreto, as garantias do artigo $113^{\circ}$ da Constituição foram suspensas. A introdução do artigo apresentou as seguintes garantias individuais: "A Constituição assegura a brasileiros e a estrangeiros residentes no país a inviolabilidade dos direitos concernentes à liberdade, à subsistência, à segurança individual e à propriedade [...]” (A TARDE, 24/03/1936). 


\title{
DA CONSTITUIÇÃO DE 1934 AO GOLPE DO ESTADO NOVO: AUTORITARISMO E DISPUTAS POLÍTICAS EM TEMPOS DE DEMOCRACIA LIBERAL-BURGUESA
}

Este foi o primeiro de uma série de decretos que mantinha em suspenso a Constituição, somente há pouco promulgada. Na verdade, o mesmo decreto foi sendo renovado até junho de 1937 e, mais tarde, em outubro, foi aplicado novamente (GUEIROS, 1996, p. 174). Significou, no entanto, o crescimento do autoritarismo, ainda que formalmente se conservassem as instituições definidas em 1934 (DULCI, 1986, p. 62).

\begin{abstract}
Para o governo, contudo, [o levante de 1935] serviu de motivo para o recrudescimento da ação repressiva. O estado de sítio foi decretado, ampliando-se mais tarde no "estado de guerra". O Congresso, através de sucessivas concessões, avalizava a orientação antidemocrática que passava a prevalecer. O fantasma da subversão da esquerda era utilizado para atemorizar a opinião liberal. As medidas de exceção, assim, recebiam o suporte das oligarquias situacionistas, de exército, da igreja, do Integralismo, de setores médios e empresariais. Após atingir a ANL, alcançaram os sindicatos, as organizações de base operária, os militares de esquerda ou simplesmente 'suspeitos, intelectuais e parlamentares. Em 1936, o Congresso aprovou a criação do Tribunal de Segurança Nacional. (DULCI, 1986, p.62).
\end{abstract}

Os decretos de estado de sítio e de guerra foram constantes a partir do levante comunista. Esse fato se tornou a justificativa perfeita para o recrudescimento da proposta de centralização política que veio à tona desde 1930. Mesmo as negociações e as articulações que desembocaram na Constituição de 1934 foram, de algum modo, controladas pela presidência e a sua aliança com militares. A suspensão dos direitos civis e a interferência direta no poder legislativo, inclusive com a prisão de deputados, foram constantes nessa conjuntura e com o aval dos parlamentares (DEMIER, 2013, 111-147). Desse modo, "a aquiescência do Congresso em legislar com poderes de emergência reforçou, sem dúvida, as tendências centralizadoras e autoritárias do regime" "xii . Chegando-se, assim, ao fim de um breve intervalo democrático vivido pelo país, entre a promulgação da Constituição e março de 1936 (NETO, 2013, p. 265).

As imunidades dos parlamentares foram suspensas a partir do decreto e não tardou para que a repressão recaísse sobre aqueles que eram suspeitos de ligação com os comunistas. Sendo assim, em 23 de março, foram presos os deputados Abguar Bastos, Domingos Velasco, João Mangabeira, eleito pela Concentração Autonomista da Bahia (A TARDE, 25/03/1936) e Otávio da Silveira, além do senador Abel Chermont, depois que a polícia invadiu o prédio da sede do parlamento brasileiro. A explicação do chefe de Polícia para a operação foi lacônica e parece que foi aceita sem maiores questionamentos por parte do presidente. Ao saber da prisão dos parlamentares, Vargas registrou o seguinte, em seu diário pessoal: “mandei indagar ao chefe de 


\section{DA CONSTITUIÇÃO DE 1934 AO GOLPE DO ESTADO NOVO: AUTORITARISMO E DISPUTAS POLÍTICAS EM TEMPOS DE DEMOCRACIA LIBERAL-BURGUESA}

Polícia e tive a confirmação de que não podia deixar de prendê-los à vista do que havia descoberto" (VARGAS, 1995, p. 490).

O Tribunal de Segurança Nacional, aprovado pelo Congresso, foi mais uma coluna erguida para o edifício da escalada autoritária. O tribunal:

Era uma corte extraordinária, concebida para julgar especialmente os que haviam sido apanhados pelos tentáculos da Comissão de Repressão ao Comunismo. Grande parte dos detidos nem sequer tinham processos abertos contra si. Estavam presos sem acusação formal, por simples ato de força do estado de exceção (NETO, 2013, p. 266).

Além disso:

A competência do TSN retroagia, permitindo-lhe julgar crimes cometidos sob a vigência de leis mais liberais. A lei introduziu a controvertida figura do julgamento por livre convicção, interpretada pela maioria dos juízes com a prerrogativa de condenar ou absolver por mera atitude mental ${ }^{\text {xiii. }}$.

O decreto do Estado de Guerra, aliado à LSN, às emendas na Constituição e o Tribunal de Segurança Nacional foram instrumentos implantados com a justificativa de criarem condições de punições mais severas para aqueles que eram considerados os inimigos do regime. A partir de então, a Carta Magna tornou-se, efetivamente, letra morta, com a anuência da maioria dos deputados e senadores.

Vargas atuou livremente na perseguição aos seus adversários e, principalmente, aliados com potencial para rivalizar com o seu poder. A caça às bruxas continuou com a prisão de Pedro Ernesto, prefeito do Rio de Janeiro, acusado de simpatizar com o "credo vermelho" e de participação no movimento. Estava, dessa maneira, aberto o caminho para o recrudescimento da escalada autoritária do regime. Conforme a análise de Dulci (1986), a ofensiva contra o parlamento foi apoiada pelo próprio, através da ação da Maioria, a partir de um processo de expurgo autofágico. O declínio das liberdades políticas foi reforçado pelo aumento do controle do Executivo sobre o Legislativo e sobre os governos estaduais (DULCI, 1986, p. 62).

Se, por um lado, Vargas continuava a montagem do seu aparato repressivo, que teve início logo após a promulgação da Constituição, com a aprovação da LSN, por outro lado, o tabuleiro político já iniciava as suas movimentações, em busca de delimitar os espaços e os nomes que deveriam se cacifar para intervir na escolha das candidaturas para a próxima eleição presidencial, prevista para janeiro de 1938. E os movimentos começaram já em 1935. O presidente, em seu diário, em tom de desaprovação, fez o seguinte comentário, no dia 4 de abril: 


\section{DA CONSTITUIÇÃO DE 1934 AO GOLPE DO ESTADO NOVO: AUTORITARISMO E DISPUTAS POLÍTICAS EM TEMPOS DE DEMOCRACIA LIBERAL-BURGUESA}

“O Jornal publicou uma entrevista do Osvaldo [Aranha] lançando a candidatura do Armando [Sales] à futura sucessão presidencial". O descontentamento foi alimentado ainda mais pelo ataque que o seu ministro lançou sobre a LSN (VARGAS, 1995, p. 376). Outro gaúcho, o governador do Rio Grande do Sul, Flores da Cunha, foi também contrário à Lei e ainda orientou o voto da sua bancada contra o projeto do governo, alimentando, desse modo, um processo gradativo de hostilidades e desconfianças.

O decreto do Estado de Guerra foi outro ponto que gerou discórdia entre Vargas e Flores da Cunha e o apoio cada vez mais explícito da candidatura de Armando Sales da parte do governador do Rio Grande do Sul contribuiu para azedar cada vez mais a relação entre os dois gaúchos. A situação já chegara em um nível de quase intervenção federal, arquitetada por Góes Monteiro (GUEIROS, 1996, p. 174-175). E nesse clima de conspirações e tentativas de golpe, Juracy Magalhães acabou sendo envolvido indiretamente:

Flores envio-me um dos seus filhos, Tonico, para denunciar a conspiração que se armava contra ele e pedir-me apoio. Achei que não tinha como envolver o povo baiano naquela briga de gaúchos bem armados. [...], eu nunca pensaria em aderir a um movimento armado em favor de Flores da Cunha no Rio Grande do Sul. Não tinha como, nem desejava meter-me naquela escaramuça (GUEIROS, 1996, p. 175).

O governador da Bahia, na conjuntura em questão, estava em uma situação delicada, diante do presidente da República. As suspeitas sobre a participação do seu irmão no movimento de novembro de 1935 continuavam a recair sobre ele. Tendo em vista que, precisou se justificar pessoalmente, além de necessitar do reforço do seu correligionário, Clemente Mariani e do seu outro irmão, Jurandir Magalhães que, em visita a Vargas, buscou isentá-lo de qualquer culpa nesse fato. Além disso, precisava lidar com o fato de estar sendo monitorado pelas forças da repressão do regime. E ele tinha plena consciência disso. Portanto, participar das conspirações com Flores da Cunha poderia ser temerário, naquele contexto. E mais do que isso, precisava reafirmar a lealdade da Bahia ao governo federal. Em carta endereçada a Vargas, em 8 de fevereiro de 1936, Juracy Magalhães procurou negar qualquer participação nas articulações gaúchas e repetiu o compromisso e lealdade da Bahia ao regime:

O acordo gaúcho é, fora de dúvida, com a pretensão de estende-lo à esfera federal, uma demonstração a mais do açodamento com que se procura cuidar do problema de sua sucessão na Presidência da República. [...]. De uma forma ou de outra, para uma hipótese ou para outra, Vossa Excelência contará, 


\section{DA CONSTITUIÇÃO DE 1934 AO GOLPE DO ESTADO NOVO: AUTORITARISMO E DISPUTAS POLÍTICAS EM TEMPOS DE DEMOCRACIA LIBERAL-BURGUESA}

indiscutivelmente, com o apoio da Bahia. Será um modesto "pião" que Vossa Excelência, com o patriotismo e a inteligência habituais, movimentará no sentido do interesse nacional [...] (MAGALHÃES, 1982, p.272-273).

Na mesma correspondência, o governador da Bahia não se furtou a apresentar uma fórmula para a resolução da questão da sucessão presidencial. E faria isso, novamente, em outras oportunidades, uma vez que ele se julgava "imaginoso" em fórmulas políticas:

[O estado da Bahia] Tem sido distinguido, politicamente, por Vossa Excelência no mais alto grau que lhe permitia seu espírito de justiça, dentro das restrições morais e equitativas do regímen federativo. Para lhe falar com a necessária e costumeira sinceridade, devo dizer-lhe que a consagração política de minha obra de governo seria ver Vossa Excelência encaminhar sua sucessão para um nome de político baiano que também fosse nacional (MAGALHÃES, 1982, p. 273).

Juracy Magalhães buscou, a partir da missiva, demonstrar para Vargas, muito mais do que a sua fidelidade e compromisso, que ele poderia também ser um aliado útil para encontrar soluções à grave situação política que se apresentava. Para tanto, se valeu da presença de correligionários seus em postos de destaque no cenário político nacional, tais como Marques dos Reis e Medeiros Neto, ministro da Viação e Presidente do Senado, respectivamente, além do deputado federal Clemente Mariani, líder da bancada governista da Bahia.

No entanto, em um jogo de mostrar e esconder, ele se apresentou novamente submisso à vontade do presidente, deixando claro que cabia ao chefe supremo da nação a decisão, a palavra final, o posto de "árbitro", "em cuja sua palavra seria o rumo da solução a adotar-se. Sobram-lhe qualidades para ter direitos a esse posto, em que sempre o considera a política baiana" (MAGALHÃES, 1982, p. 273).

Ao longo dos anos de 1936 e 1937, além das questões relacionadas aos decretos do Estado de Sítio e do Estado de Guerra, com todas as suas prorrogações, as perseguições aos considerados inimigos do regime, o tema que mais ocupou o cenário político do país foi o das eleições presidenciais, marcada para ocorrer em janeiro de 1938. Juracy Magalhães relatou, em suas memórias, o intrincado processo de negociações, de acordos feitos e desfeitos, de desconfianças mútuas em que se envolveram algumas das principais lideranças políticas do país. Entre eles, o próprio governador da Bahia, além de Flores da Cunha, Armando Sales de Oliveira, Benedito Valadares e Carlos de Lima Cavalcanti, respectivamente chefes do executivo do Rio Grande do Sul, São Paulo, Minas Gerais e Pernambuco. A princípio, todos estavam em 


\section{DA CONSTITUIÇÃO DE 1934 AO GOLPE DO ESTADO NOVO: AUTORITARISMO E DISPUTAS POLÍTICAS EM TEMPOS DE DEMOCRACIA LIBERAL-BURGUESA}

busca de uma solução, um nome que fosse consensual e que contasse, de igual modo, com o aval de Getúlio Vargas, embora o presidente, em seu diário, demonstrasse pouco interesse, ou, até mesmo, hostilidade quando se tratava desse tema.

Os sinais de Vargas acerca da questão eram, para dizer o mínimo, ambíguos. Paulo Brandi destacou as ações do presidente, em 1936, que demonstravam que ele não estava disposto a abrir mão da sua sanha autoritária e centralizadora ${ }^{\text {xiv }}$. Nesse meio tempo, ele não aceitou um compromisso de trégua que seria firmado entre o governo e a oposição, visando a “pacificação política”, por intermédio de Flores da Cunha, cada vez mais abertamente contrário à centralização em curso, e João Neves da Fontoura. Dois dos principais nomes da Frente Única Gaúcha, que contava ainda com a participação de Borges de Medeiros e Raul Pila. Vargas, com efeito, "marchava claramente para a consolidação de seu poder pessoal especulando continuamente com a ameaça comunista, largamente fabricada pelo próprio governo" ${ }^{\mathrm{xv}}$.

Vale ressaltar que as medidas de exceção contavam com largo apoio de importantes setores das classes dominantes que, prontamente, através dos seus representantes no Congresso, decretaram a prorrogação do Estado de Guerra em junho de 1936. O Tribunal de Segurança Nacional foi outro instrumento repressivo que representava mais uma pá de cal no caixão da natimorta Constituição. O seu funcionamento ocorreu a partir de dezembro de 1936 e, segundo a justificativa do decreto-lei que garantiu a sua existência, "Suas normas eram de molde a eliminar o 'doloroso anacronismo' jurídico que segundo Vicente Rao desarmava o Estado na 'luta contra os seus inimigos"',xvi.

A partir do segundo semestre de 1936, já rondavam, nos círculos políticos mais íntimos do presidente, rumores da possibilidade de um golpe que manteria Vargas no poder. A aproximação dele com Góis Monteiro e Francisco Campos, tornavam o fato cada vez mais plausível, devido a inclinação doutrinária de ambos “à implantação de um estado autoritário"xvii. Góis foi responsável para traçar um plano para um Estado ditatorial, enquanto Francisco Campos recebeu a incumbência de redigir uma nova constituição que deveria ser imposta através de um golpe de Estado ${ }^{\text {xviii }}$. Além desses, Benedito Valadares era mais um entusiasta da saída golpista. Em 19 de agosto de 1936, Vargas, em seu diário, se referiu ao governador mineiro do seguinte modo: "Achei-o também muito decidido a um golpe de Estado, no sentido de dissolver o Congresso e outorgar uma nova Constituição" (VARGAS, 1995, p. 536).

Diante dos sinais e ações de Vargas, Juracy Magalhães compreendeu que a continuidade do presidente, via prorrogação de mandato, ou, simplesmente, através de um golpe de Estado, 


\title{
DA CONSTITUIÇÃO DE 1934 AO GOLPE DO ESTADO NOVO: AUTORITARISMO E DISPUTAS POLÍTICAS EM TEMPOS DE DEMOCRACIA LIBERAL-BURGUESA
}

era uma realidade naquela conjuntura. Portanto, utilizou-se da inauguração da sede do Instituto do Cacau, em 20 de novembro de 1936, que contou com a presença do presidente, além de diversas autoridades como ministros de Estado, governadores, deputados e demais lideranças políticas para fazer um discurso, proferido um dia depois, em que elencava as características do próximo presidente do Brasil. Segue um trecho do discurso:

\begin{abstract}
O Partido Social Democrático da Bahia, que nunca se deixou ultrapassar na lealdade imutável, na fidelidade permanente, no apoio intransigente e na solidariedade invariável ao grande chefe da Revolução de Outubro, vem, ainda uma vez, dizer, de público, o seu propósito decidido de colaborar, a todo o poder que o possa, com elevação e patriotismo, na hora oportuna, no grande problema que é a sucessão presidencial. Por si só já constitui uma contingencia circunstancial da maior importância, ter de suceder-se a um estadista invulgar como Getúlio Vargas. A Bahia vem dizer ao Brasil e a seu grande Presidente que o seu candidato, na oportunidade justa, só poderá ser um cidadão: $o$ melhor entre os mais capazes (IGHB, Discursos, 82-5 M188, 21/11/1936, p. 16-17) (grifo do autor).
\end{abstract}

No trecho, percebem-se duas questões principais. Em primeiro lugar, a declaração de que as forças políticas baianas sob a liderança de Juracy Magalhães, reunidas no PSD, estavam completamente ligados por laços de fidelidade, apoio e solidariedade ao presidente, ainda referido como o chefe da Revolução de 1930. Na verdade, foi a continuação de uma série de agradecimentos e elogios feitos anteriormente, no início do pronunciamento. O governador falava, supostamente, pelos seus correligionários. Em seguida, ele impôs na ordem do dia a questão que era tão sensível e que Vargas queria evitar a todo custo naquela conjuntura, a saber: a sucessão presidencial.

Ao afirmar que o candidato à presidência apoiada pela situação baiana deveria ser $o$ melhor entre os mais capazes, Juracy Magalhães destacou, ainda, que ele deveria garantir “o aval das suas tradições e o endosso do seu passado político, a defesa racional da obra lapidar de 16 de julho [a Constituição de 1934], o combate ininterrupto a todos os inimigos da democracia" (IGHB, Discursos, 82-5 M188, 21/11/1936, p. 17), além de "manter todas as conquistas brasileiras no departamento das urnas livres e soberanas", bem como ter "a sabedoria política de atualizar o regime democrático, adaptando as fórmulas e processos à realidade contemporânea" (IGHB, Discursos, 82-5 M188, 21/11/1936, p. 18). Com efeito, ao apontar características que seriam supostamente atribuídas a Vargas e que precisariam ser defendidas pelo candidato escolhido, Juracy Magalhães fazia uma crítica velada a todos os ataques à 


\section{DA CONSTITUIÇÃO DE 1934 AO GOLPE DO ESTADO NOVO: AUTORITARISMO E DISPUTAS POLÍTICAS EM TEMPOS DE DEMOCRACIA LIBERAL-BURGUESA}

Constituição desferidos pelo presidente, desde a sua promulgação e que recrudesceu após novembro de 1935.

A reação do presidente ao discurso não foi das mais animadas, segundo o relato memorialístico de Juracy Magalhães, "Dr. Getúlio demonstrou insatisfação, mas quando conversamos deu a entender que o problema da sucessão já não existia” (MAGALHÃES, 1982, p. 100). Essa não foi a primeira, nem a última, mensagem proferida com teor semelhante naquele interregno, a de uma defesa genérica da democracia e a necessidade de eleições periódicas e da alternância no poder, desde que não se descuidasse do perigo das massas.

Há pouco menos de um mês antes desta solenidade, em 30 de outubro de 1936, falando para a Associação dos Empregados do Comércio, Juracy Magalhães defendeu que a carta constitucional "é a indumentária propícia e apropriada para o clima e o organismo nacionais" (IGHB, Discursos, 82-5 M188, 30/10/1936, p. 12) e que era preciso "atualizar o regimen democrático, mantendo os princípios nucleares do voto, da representação das minorias, da rotatividade e limitação no exercício do poder" (IGHB, Discursos, 82-5 M188, 30/10/1936, p. 16). No mesmo dia em que apregoou contra o fascismo e o bolchevismo, em 1937, afirmou o seguinte: "através deles [os partidos políticos] se estabelece o rotativismo nos postos de direção da máquina do Estado, com a transformação das maiorias em minorias e das minorias em maiorias" (MAGALHÃES, 1957, p. 165), mais abaixo ele ratificou a ideia, defendendo que "um outro princípio básico do regime [democrático] é a limitação de prazo no exercício do poder" (MAGALHÃES, 1957, p. 165).

Não havia coincidências quando, em um tempo muito curto, entre outubro de 1936 e início de 1937, três discursos foram proferidos e trataram todos eles das mesmas questões, utilizando-se quase ipsis litteris dos mesmos termos e ideias. O que se pode inferir é que isso significava um sinal claro do afastamento entre as duas lideranças políticas.

Enquanto Vargas apostava todas as fichas no fechamento do regime, desde a promulgação do texto constitucional, por seu turno, Juracy Magalhães passou a defender a democracia, o que ele chamava de "espírito de 14 de julho", com eleições livres e, principalmente, a rotatividade do poder. Tudo isso a despeito das declarações públicas e das cartas enviadas ao presidente que queriam demonstrar lealdade, apoio e gratidão.

Por seu turno, na intimidade do seu diário, as opiniões de Vargas a respeito do governador da Bahia não eram das mais lisonjeiras. Benedito Valadares, fazendo às vezes de informante do presidente, relatou que o governador da Bahia lhe confidenciara que havia 


\section{DA CONSTITUIÇÃO DE 1934 AO GOLPE DO ESTADO NOVO: AUTORITARISMO E DISPUTAS POLÍTICAS EM TEMPOS DE DEMOCRACIA LIBERAL-BURGUESA}

perdido a confiança em Vargas e que tinha receios sobre o futuro. De posse dessa informação, Vargas julgou Juracy Magalhães da seguinte maneira: "novo, envaidecido, trabalhado por intrigas, deseja ser amigo e sincero, mas é atuado por forças contrárias" (VARGAS, 1995, p. 569). Com efeito, não era a primeira vez que o presidente tecia comentários negativos acerca do "jovem" governador da Bahia e, novamente, o considerava influenciável por forças que considerava inimigas do regime.

Em suas memórias, Juracy Magalhães relatou que foi contactado, por um enviado de Vargas, a respeito da possibilidade da sua participação em um golpe. No dia 24 de junho de 1936, em um jantar na casa do advogado baiano, deputado federal e ministro da Viação, Marques dos Reis, ele recebeu do ministro de Trabalho, Agamenon Magalhães, o seguinte convite:

- Juracy, tenho uma missão do presidente junto a você. Ele acha que a revolução não realizou ainda seus objetivos e será necessário prolongar seu tempo de duração. Isto só pode ser feito através de um golpe de Estado que estenda o mandato dele e de seus governadores. Sua colaboração será imprescindível. (GUEIROS, 1996, p.178).

Em conversa com Vargas sobre o assunto, Juracy afirmou que era contra a solução do golpe: “- Acho que não realizamos uma obra de governo para nos impormos como insubstituíveis. Melhor será se passarmos o poder aos nossos sucessores legais.” Ao que Vargas respondeu, tentando explorar o senso de companheirismo de 1930 “- Ora, Juracy, essa é uma ideia que eu só poderia desenvolver com o consenso dos amigos do teu porte. Se pensas em vetá-la, já a considero afastada." (GUEIROS, 1996, p.179).

Na tréplica, Juracy seguiu negando a participação e o apoio para uma saída golpista, naquela conjuntura:

- Não é o caso, presidente, pois não me sinto com o poder de veto, mas informo que vou fazer uma operação de apendicite e não custa dizer que demorarei a recuperar-me. Renuncio ao governo da Bahia e o senhor me substitui por uma pessoa mais afinada com seu pensamento político. O senhor está regendo sua orquestra. Eu serei um instrumento desafinado nesta orquestra. [...]. Servi à ditadura que se seguiu à Revolução porque o senhor tinha o compromisso de restabelecer a ordem democrática em nosso país, mas agora vejo que pretendo instalar um Estado autoritário puro e simples. Não conte comigo (GUEIROS, 1996, p.179).

Vargas, aparentemente, afastou a ideia. No entanto, já era um fato para o governador da Bahia que o presidente não demonstrava nenhum sinal de que iria deixar o poder no prazo 


\section{DA CONSTITUIÇÃO DE 1934 AO GOLPE DO ESTADO NOVO: AUTORITARISMO E DISPUTAS POLÍTICAS EM TEMPOS DE DEMOCRACIA LIBERAL-BURGUESA}

estabelecido pela Constituição: "Estava claro que nunca desistiria de sua intensão golpista. Vi que não adiantava mais ficar ali contemporizando e logo me retirei.” (GUEIROS, 1996, p.180).

O ano de 1936 terminara com mais uma prorrogação do Estado de Guerra, decretado em 14 de dezembro (VARGAS, 1995, p. 568). E o ano de 1937 iniciou com as discussões em torno da escolha dos candidatos à eleição que deveria ocorrer um ano depois. E o processo foi desencadeado junto ao público, justamente, no episódio da inauguração da sede do Instituto do Cacau da Bahia, a partir do discurso acima referido. As tratativas visavam exatamente barrar as tendências continuístas do presidente. Nesse caso, o papel desempenhado por Juracy Magalhães foi fundamental. De acordo com Brandi, citando Hélio Silva:

O governador da Bahia tentou em seguida articular uma aliança com São Paulo, Minas, Rio Grande do Sul e Pernambuco para garantir as eleições. Lima Cavalcanti, de Pernambuco, concordou. Em encontro com Armando Sales, Juraci propôs a apresentação de uma lista tríplice a Vargas, para que o presidente escolhesse um candidato oficial. A lista em questão incluía os nomes de Armando Sales, José Américo de Almeida e Antônio de Medeiros Neto $^{\text {xix }}$.

Em suas memórias, Juracy Magalhães abordou esta questão da seguinte maneira:

Eu, Flores da Cunha, Benedito Valadares, Armando de Sales e Lima Cavalcanti, quase todos amigos do dr. Getúlio, iríamos ao presidente e exporíamos o nosso pensamento, de que chegara a hora de se articular um nome para substituí-lo. Sugeri uma lista tríplice a ser submetida ao dr. Getúlio. O primeiro nome era Armando de Sales Oliveira, governador de São Paulo, que tinha sido escolhido interventor pelo próprio presidente. O outro, Medeiros Neto, presidente do Senado, homem da maior confiança do dr. Getúlio, mais amigo dele do que meu. E finalmente, José Américo, que era meu amigo, mas tinha sido ministro de dr. Getúlio e mantinha com ele uma boa amizade (MAGALHÃES, 1982, p. 100).

Apesar dos esforços para que fosse estabelecido um consenso em torno de um nome que viesse representar as forças políticas da maioria, isso não ocorreu. Em parte, por causa da intransigência de Armando Sales que não abria mão da sua candidatura. A sua intenção foi concretizada com a sua renúncia do governo de São Paulo, em 30 de dezembro de 1936 e da negativa de Vargas em apoiar o nome de um governador, para não ficar refém de uma "política dos governadores" ${ }^{\prime x x}$.

No decorrer do ano foram se delineando as candidaturas de acordo com a correlação das forças políticas em disputa, à revelia das fórmulas imaginadas à priori. Nesse caso, "o equilíbrio 


\section{DA CONSTITUIÇÃO DE 1934 AO GOLPE DO ESTADO NOVO: AUTORITARISMO E DISPUTAS POLÍTICAS EM TEMPOS DE DEMOCRACIA LIBERAL-BURGUESA}

entre a tendência ao fortalecimento do poder central e os interesses dos vários grupos políticos nos estados da Federação se fazia cada vez mais difícil”xxi .

O cenário da conjuntura foi descrito por Juracy Magalhães do seguinte modo:

Vargas estava articulando seu golpe de 37, mas nós ainda acreditávamos na hipótese de forçar eleições para a presidência da República em 1938. Os políticos mais influentes já haviam proposto suas candidaturas[...] (GUEIROS, 1996, p. 180).

Por outro lado, além de Armando Salles, governador paulista, que renunciou ao cargo para entrar na disputa, Getúlio o considerava um representante da burguesia paulista, por isso apoiou José Américo. Juarez Távora e João Aberto estavam divididos. Benedito Valadares ficou em cima do muro e Plinio Salgado tinha o apoio dos integralistas. Clemente Mariani apoiou José Américo. Valadares inicialmente preferia a continuidade de Vargas, mas quando percebeu a opinião pública se voltar para as eleições, resolveu apoiar José Américo. (GUEIROS, 1996, p. 180). E, no final das contas, o próprio governador da Bahia que inicialmente estava comprometido com Armando Sales de Oliveira, se engajou na campanha à presidência do escritor e político paraibano.

Enquanto os governadores, acima destacados, estavam em Poços de Caldas conferenciando sobre o (os) possível (eis) nome (es) para a candidatura nas próximas eleições presidenciais, Vargas fazia votar, na Câmara dos Deputados, mais uma prorrogação, por noventa dias, do Estado de Guerra, no dia 10 de março de 1937 (VARGAS, 1995b, p. 23-25).

\section{O CAMINHO PAVIMENTADO PARA O GOLPE DO ESTADO NOVO}

A partir de março e abril de 1937, houve um intenso monitoramento, por parte das forças de repressão de Vargas, à situação política na Bahia. O presidente recebia relatórios e informes de diversas fontes, inclusive do governador de Minas Gerais (VARGAS, 1995b). O que fica patente, é que ele não ficou satisfeito com os movimentos de Juracy Magalhães na articulação dos nomes dos presidenciáveis: “esses nomes seriam, porém, indicados ao exame após uma consulta às principais correntes políticas. Não me parece que só [...] São Paulo e Bahia possam indicar nomes entre os quais deva ser escolhido o candidato" (VARGAS, 1995b, p. 15).

Outrossim, passaram a circular rumores a respeito das ações de Juracy Magalhães e do cenário interno da política na Bahia. Em primeiro lugar, um possível rompimento entre os dois, 


\section{DA CONSTITUIÇÃO DE 1934 AO GOLPE DO ESTADO NOVO: AUTORITARISMO E DISPUTAS POLÍTICAS EM TEMPOS DE DEMOCRACIA LIBERAL-BURGUESA}

presidente e governador, surgindo, desse modo, uma situação em que se digladiariam na política baiana um partido de Getúlio Vargas versus um partido de Juracy Magalhães (CPDOC/FGV, AT c 1937.04.27). Em seguida, foi aventada a possibilidade de uma aliança entre Juracy Magalhães e setores da oposição baiana, o que foi negada por um dos principais nomes desse grupo, o deputado Nestor Duarte (CPDOC/FGV, AT c 1937.04.24/1; VARGAS, 1995b, p. 20). Igualmente, tratou-se a respeito de uma situação de enfraquecimento da posição do governador da Bahia no seio do seu grupo político, que estaria se dividindo em três correntes distintas, notadamente a partir de desentendimentos dele com Marques dos Reis, ministro da Viação, em torno de divergências sobre o nome que deveria ser apoiado pela Bahia (CPDOC/FGV, GV c 1937.01.00). Outro fato que demonstrava a perda progressiva de prestígio de Juracy Magalhães nos meios políticos e que corroborava com a questão acima, foi a circulação da informação de que estaria sendo articulada a deposição do governador e que o substituto seria o seu correligionário de primeira hora, Pacheco de Oliveira (CPDOC/FGV, AT c 1937.00.00/1). E, por fim, ainda em abril de 1937, uma conversa entre o ministro da Justiça, Agamenon Magalhães, e o ministro da Guerra, Eurico Gaspar Dutra, teve como tema principal a ocupação militar no Rio Grande do Sul, na Bahia e em São Paulo, cujo pretexto era um pacto de defesa mútua que havia sido firmado entre os governadores dos três estados (VARGAS, 1995b, p. 31).

Nessa linha de ação ele estabeleceu uma intervenção velada em Estados governados por aliados como Bahia, São Paulo e Pernambuco, a partir da nomeação de executores do estado de guerra, em 29 de abril de 1937. Dessa maneira, Vargas passaria a ter um controle mais efetivo sobre as ações dos governadores, uma vez que os militares responsáveis pela execução do estado de guerra se reportariam apenas ao presidente (BPEBa, DIÁRIO DE NOTÍCIAS, 29/04/1937). Em seguida, Flores da Cunha foi afastado do cargo no Rio Grande do Sul, a partir da alegação de que ele estava estocando armas para se rebelar contra o governo central. Igualmente, Lima Cavalcanti, governador de Pernambuco, também foi preso sob a acusação de ligações com o comunismo (BPEBa, DIÁRIO DE NOTÍCIAS, 08/05/1937).

Nesse ínterim, Vargas consultou alguns dos seus auxiliares mais próximos a respeito da conveniência de mais uma prorrogação do Estado de Guerra, em junho de 1937. Os ministros da Justiça e da Guerra consideraram razoável a não prorrogação, ao contrário do chefe de polícia e do presidente do Tribunal de Segurança Nacional, que insistiam nesta saída. Em um registro importante, Vargas salientou a recusa de Juracy Magalhães em aceitar a ampliação do prazo do dispositivo de exceção e que esse havia instruído os seus correligionários a votarem contra a 


\section{DA CONSTITUIÇÃO DE 1934 AO GOLPE DO ESTADO NOVO: AUTORITARISMO E DISPUTAS POLÍTICAS EM TEMPOS DE DEMOCRACIA LIBERAL-BURGUESA}

medida. Expirado o prazo, o Estado de Guerra caducou e com isso presos foram soltos e a censura foi suspensa (VARGAS, 1995b, p. 52-53). No entanto, em outubro de 1937, o Estado de Guerra foi novamente decretado por ampla maioria no Congresso e que ainda contou com cumprimentos dos deputados ao presidente (VARGAS, 1995b, p. 72).

Juracy Magalhães passou a ser investigado e intimidado pelo Coronel Antônio Fernandes Dantas, o executor do Estado de Guerra na Bahia. Entre os motivos dos conflitos entre os dois militares estavam: a alegação de que o governador da Bahia não havia se empenhado na repressão ao comunismo, além de que prestigiaria a notórios chefes da ANL; a suspeita de que o governo estadual estava estocando armas e o veemente protesto de Juracy Magalhães contra a prisão dos deputados oposicionistas Péricles Noblat, Crescêncio Lacerda, Nestor Duarte, Álvaro Sanches, Aliomar Baleeiro e Maria Luiza (MAGALHÃES, 1982, p. 283286; 288-289).

Pouco antes do golpe ser definitivamente assestado, Getúlio Vargas, novamente, sondara a possibilidade de contar com o apoio de Juracy Magalhães e utilizou-se, para isso, da intermediação do seu ministro da Viação: “pouco depois, no momento do golpe, dr. Getúlio, maliciosamente, mandou Marques dos Reis oferecer-me uma ponte para eu aderir. Não aceitei[...]" (MAGALHÃES, 1982, p. 103). À recusa, o presidente respondeu com intimidação militar: "aprestam-se os movimentos para uma reforma constitucional. Serão tomadas medidas de controle militar sobre Pernambuco, Bahia e São Paulo, tidos como estados não-conformistas com a reforma" (VARGAS, 1995b, p. 77). E ela se concretizou da seguinte maneira:

Pouco antes, dr. Getúlio me prestara uma grande homenagem de enviar à
Bahia o cruzador Rio Grande do Sul, uma bateria de artilharia e um batalhão
de Infantaria de Juiz de Fora, comandados por dois colegas meus de turma. O
dispositivo se completava com um batalhão de Sergipe que tomou posição no
interior. Este esquema militar me tiraria qualquer possibilidade de reagir.
Entretanto, como não tinha essa intenção, recebi o movimento de tropas como
uma comprovação de que o golpe era iminente, enviando um telegrama de
protesto ao general Dutra. [...]. Medeiros Neto, João Pacheco de Oliveira e
João Marques dos Reis, três próceres da minha corrente política, estavam com
Vargas (MAGALHÃES, 1982, p. 104).

No trecho final, Juracy Magalhães demonstrou ressentimento com relação a aqueles que ele acreditava ter sido fundamental na ascensão política, lamentando o que ele considerava uma traição: "E, para tristeza minha, os amigos e correligionários [...] que eu tanto ajudara na 


\section{DA CONSTITUIÇÃO DE 1934 AO GOLPE DO ESTADO NOVO: AUTORITARISMO E DISPUTAS POLÍTICAS EM TEMPOS DE DEMOCRACIA LIBERAL-BURGUESA}

ascensão política, tinham aderido a Getúlio, me deixando para trás. A ambição política falou mais alto do que a gratidão" (GUEIROS, 1996, p. 186).

A partir de 10 de novembro de 1937, com o Estado Novo, houve um fortalecimento do poder executivo, com intensa propaganda oficial e perseguição aos adversários políticos, visando à construção de uma imagem positiva do regime. Esse foi construído a partir da formação de um dispositivo militar, aliado ao fortalecimento da burocracia estatal, que, dotada de relativa autonomia em relação as classes sociais, empreendeu o processo de aceleração da industrialização no país e deu sustentação a Vargas. No entanto, as oposições, formadas pelas oligarquias alijadas em 1930, em aliança com aqueles que romperam com o bloco no poder, fortaleceram suas atividades conspiratórias, a partir do início da década de 1940. Contando com o auxílio de militares, que outrora foram sustentáculos da ditadura, derrubaram Vargas e reestabeleceram a democracia liberal em 1945.

\section{Fontes:}

Diário da Bahia (1931-1937)

A Tarde (1931-1937)

\section{Diário de Notícias (1931-1937)}

Correio da Manhã (1935)

Exposição feita ao Presidente da República Getúlio Vargas pelo Interventor Federal, Capitão Juracy Magalhães (1935).

Mensagem do Governador Juracy Magalhães relatando à Assembleia Legislativa, em 2 de julho de 1936, a situação geral do Estado da Bahia (1936).

Mensagem do Governador Juracy Magalhães relatando à Assembleia Legislativa, em 2 de julho de 1937, a situação geral do Estado da Bahia (1937).

Discurso pronunciado em Salvador, em 20 de outubro de 1936, na sede da Associação dos Empregados do Comércio.

Discurso pronunciado em Salvador, em 21 de novembro de 1936, quando da inauguração do Instituto do Cacau.

Discurso pronunciado em Salvador, em 1937 [sem data definida], na ocasião da visita do governador do estado de Sergipe.

Acervos do CPDOC/FGV (Getúlio Vargas, Clemente Mariani, Juracy Magalhães, Anísio Teixeira). 


\section{DA CONSTITUIÇÃO DE 1934 AO GOLPE DO ESTADO NOVO: AUTORITARISMO E DISPUTAS POLÍTICAS EM TEMPOS DE DEMOCRACIA LIBERAL-BURGUESA}

\section{REFERÊNCIAS}

BRANDI, Paulo. Getúlio Dornelles Vargas. In: ABREU, Alzira Alves et al (coods.). Dicionário Histórico-Biográfico Brasileiro - Pós-1930. CPDOC, 2010. Disponível em: $<$ https://cpdoc.fgv.br/acervo/dhbb>. Acesso em: 15/03/2020.

CARONE, Edgard. A República Nova (1930-1937). São Paulo: Difel, 1974.

DEMIER, Felipe. O Longo Bonapartismo Brasileiro (1930-1964): um ensaio de intepretação histórica. Rio de Janeiro: Mauad X, 2013.

DIAS, José Alves. Rumo ao Palácio: as estratégias de dominação dos espaços políticos na Bahia durante a Ditadura (1966-1982). Vitória da Conquista: Edições UESB, 2016.

DULCI, Otávio Soares. A UDN e o anti-populismo no Brasil. Belo Horizonte: Editora da UFMG/PROED, 1986.

DREIFFUS, René Armand. 1964: A conquista do Estado - ação política, poder e golpe de classe. Petrópolis: Vozes, 1981.

GUEIROS, José Alberto. O Último Tenente. Rio de Janeiro: Record, 1996.

MAGALHÃES, Juraci. Minha Vida Pública na Bahia. Rio de Janeiro: José Olympio Editora, 1957.

. Minhas Memórias Provisórias: depoimento prestado ao CPDOC. Rio de Janeiro: Civilização Brasileira, 1982.

NETO, Lira. Getúlio: do Governo Provisório à ditadura do Estado Novo. São Paulo: Companhia das Letras, 2013.

PANDOLFI, Dulce Chaves. A trajetória do Norte: uma tentativa de ascenso político. In: GOMES, Ângela Maria de Castro (Org.). Regionalismo e Centralização Política: partidos e constituinte nos anos 30. Rio de Janeiro: Nova Fronteira, 1980.

VARGAS, Getúlio. A Nova Política do Brasil. Rio de Janeiro: José Olímpio, 1938. (vol. 3-4). Diário. São Paulo: Siciliano; Rio de Janeiro: Fundação Getúlio Vargas, 1995. (Vol. I-

II).

\section{NOTAS:}

iDisponível em: <http://www.fgv.br/cpdoc/acervo/dicionarios/verbete-biografico/getulio-dornelles-vargas>. Acesso em: 15/03/2020.

ii Idem.

iii Idem.

iv Idem. 


\footnotetext{
v Disponível em: http://www.fgv.br/cpdoc/acervo/dicionarios/verbete-tematico/conselho-de-seguranca-nacionalcsn. Acesso em: 15/03/2020.

vi Idem.

${ }^{v i i}$ Disponível em: <http://www.fgv.br/cpdoc/acervo/dicionarios/verbete-biografico/getulio-dornelles-vargas> . Acesso em: 15/03/2020.

viii Idem

ix Idem

${ }^{x}$ Idem.

xi Idem.

xii Idem.

xiii Idem.

${ }^{\text {xiv Idem. }}$

${ }^{x v}$ Idem.

xvi Idem.

xvii Idem.

xviii Idem.

xix Idem.

${ }^{x x}$ Idem.

${ }^{\text {xxi }}$ Idem.
} 